\title{
Review Article \\ Omitted Variables in the Geographical Treatment of Well-Being and Happiness
}

\author{
Dragos Simandan \\ Geography Department, Brock University, 500 Glenridge Avenue, St. Catharines, ON, Canada L2S 3A1 \\ Correspondence should be addressed to Dragos Simandan; simandan@brocku.ca
}

Received 2 April 2014; Accepted 9 June 2014; Published 19 June 2014

Academic Editor: Siyue Li

Copyright ( 2014 Dragos Simandan. This is an open access article distributed under the Creative Commons Attribution License, which permits unrestricted use, distribution, and reproduction in any medium, provided the original work is properly cited.

\begin{abstract}
This paper provides a critical engagement with state-of-the-art research from positive psychology and behavioral genetics that directly challenges social geographers' working hypothesis that people's well-being and happiness can dramatically be improved by suitably modifying unjust social arrangements and exploitative economic relations. It is intended to generate interest in this neglected body of work in general and awareness of its politically regressive implications in particular.
\end{abstract}

\section{Introduction}

As social geographers, we work to uncover misconceived and unfair social arrangements that undermine individual and collective well-being [1]. We assume $e^{1}$ that we can substantially increase quality of life and happiness by replacing those nefarious arrangements with better ones [2-6]. Yet, our assumption has recently been challenged by a massive body of empirical work in positive psychology ${ }^{2}$ and behavioral genetics (see the review by [7], and the references cited therein), which suggests that people's level of happiness depends largely on their genetic ${ }^{3}$ make-up. In what follows, I review these worrying findings, and then end the paper with some thoughts as to how social geographers could begin to grapple with this politically regressive provocation ${ }^{4}$.

\section{Chance and Happiness}

Martin Seligman, the founding father of positive psychology, argues ([8-10]; see also [11, 12]) that the empirical research on happiness in the last few decades can be conveniently encapsulated in a threefold formula: $\mathrm{H}=\mathrm{S}+\mathrm{C}+\mathrm{V}$, where $\mathrm{H}$ is happiness, $\mathrm{S}$ is one's genetic set point ${ }^{5}, \mathrm{C}$ includes the geographical-environmental conditions of one's life, and $\mathrm{V}$ refers to factors under voluntary control. The most important and most sobering discovery in the field is that happiness is largely a stochastic phenomenon [13] and that each individual's emotional states are attracted in the long run by a specific genetic set point [14]. One can force oneself to be cheerful with conscious effort for a longer period but soon after one stops the conscious effort, the average level of mood returns ${ }^{6}$ to one's set point [15]. Affective neuroscience has recently uncovered the brain geographies that underpin these different set points. Davidson revealed experimentally ([16]; see also [17]) that a cheerful mood has its neurological correlates in increased left-brain activity, whereas a depressed mood intensifies right-brain activity. His research resonates with Coren's earlier work on left-handedness [18]. Coren investigated why left-handedness is also called sinistrality and found that the average left-hander has higher incidence of depression, anxiety, anger, antisocial tendencies, and suicide ${ }^{7}$.

A team of researchers led by Lykken and Tellegen [13] and working within the broader framework of the famous Minnesota Study of Twins Reared Apart has been particularly concerned with measuring exactly how much the set point matters in determining one's happiness. They concluded that $80 \%$ of one's average level of happiness is determined by the genetic factors alone and that, therefore, the ultimate factor that governs happiness is pure chance ([13], page 189).

It may be that trying to be happier is as futile as trying to be taller and therefore counterproductive.... If the transitory variations of well-being are largely due to fortune's favors, whereas the midpoint of these 
variations is determined by the great genetic lottery that occurs at conception, then we are led to conclude that individual differences in human happiness, how one feels at the moment and also how happy one feels on average over time, are primarily a matter of chance.

If left unchallenged ${ }^{8}$, this brutal finding would have been unsettling for the critical project in geography and for emancipatory social science, because it leaves little room for the academic left's conviction that one's happiness and well-being are determined by one's social spaces and more specifically, by the level of fairness and social justice within a given community $[1,2,19]$. In the decade since Lykken and Tellegen's discovery, positive psychologists and behavioral geneticists have become slightly more cautious about genetic determinism (cf. $[7,20]$ ) and softened the frightful " $80 \%$ " with the more vague claim that genetic factors explain only about $50 \%$ to $80 \%$ of the interindividual differences in happiness ${ }^{9}$.

As noted above, the remaining percentage is shared by environmental conditions $(\mathrm{C})$ and by factors under voluntary control (V). Not all the plausible candidates matter equally when considering environmental conditions. A pleasant physical environment, California, for example, does not make people happier [8-10]. More significantly yet, the amount of wealth contributes to happiness in a nonlinear way (cf. $[11,12,21])$ : up to a certain point, where the basic requirements of living a decent life are met, increased wealth does substantially increase happiness; beyond that point lies the land of diminishing returns. Put differently, a $\$ 10,000$ increase in one's wealth matters much more if the initial wealth is $\$ 12,000$ than if it is $\$ 120,000$. One would only hope that this finding would be widely disseminated and convincing enough to make the bourgeoisie more generous towards the public welfare. One would equally hope that, as scholars committed to the ideal of social justice, we would understand that increasing people's level of happiness can, but need not always be an evil bourgeois tactic of cultivating false consciousness. Instead, by enhancing happiness we could at least in principle ${ }^{10}$ empower people to better help themselves through work [22]. Haidt ([23]: page 89) has put it as follows.

Happy people grow rich faster because, as in the marriage market, they are more appealing to others (such as bosses) and also because their frequent positive emotions help them to commit to projects, to work hard, and to invest in their futures.

Having said these, there remain other environmental conditions that matter for happiness. Among them, the most consequential are [23] the level of noise; the amount of commuting; physical deformities that lead to shame and selfconsciousness; the quality of one's relationships (people in functional marriages are more happy than singles, but singles are more happy than people stuck in venomous marriages; [10]); the sense of control over one's environment [24]; and the quality of government (people in stable democracies are more happy than people under despotic regimes [25]).

As a general observation, the happiest people tend to have very rich networks of relatives, friends, and acquaintances
[26-28], but the arrow of causality likely goes both ways; because they are (genetically) happy, they attract and maintain fulfilling friendships, and because they spend a lot of time cultivating friendships and shared activities, they become yet more happy [29]. One detects behind this reinforcing feedback loop a "Matthew Effect," operating in line with what psychoanalysts have always known [30-32]; those who start life happy become yet happier and those who start mentally troubled become yet more troubled. The difference from traditional psychoanalysis comes, however, from the counterintuitive but solidly researched fact that the start refers mainly to one's genes and not to so much to the quality of one's childhood (for a demolition of the psychoanalytic myth that early familial environment is excruciatingly important ${ }^{11}$; see $[7,33,34])$.

Finally, the factors under voluntary control (V) in the formula of happiness refer to attitudes towards reality, to coping styles, and to practices of living. Seligman $[9,10]$ notes that depressed patients tend to have an attitude towards reality characterised by a set of five interrelated beliefs and practices. First of all, they externalise their locus of control, underestimating the extent to which they can change things [24]. Secondly, they internalise their locus of attention, focusing too much on their problems and inadequacies and succumbing to never-ending self-ruminations [35]. Thirdly, if something unpleasant happens, they interpret that event as proof of their essential inadequacy (e.g., they perceive a mild intellectual critique as evidence that they are genetically stupid[36]); fourthly, they overgeneralise in time their likelihood of failure ("I will always be a loser" [37]); and fifthly, they overgeneralise across spheres of activity (e.g., if they receive a low mark on one particular exam, they assume that they have no talent for academic work at all [37]).

Of these five factors, as social geographers we might benefit from paying close attention to the first: by teaching our students that we are socially constructed, that we are subject to forces beyond our control (capitalism, patriarchy, and parochial cultures), and that our agency is in fact a negative agency (e.g., when we will something, it is a conglomerate of internalised discourses that will the will) we may inadvertently undermine their sense of mastery and free will and thus push them on the path of negativity, renunciation, and depression. It might therefore be wise to balance our account of the social construction of subjectivities with an account of the bare life [38-40] that grounds an individual's sense of possibility, one's capability of making things happen, and one's power to overcome the forces of one's interpellation and to reconfigure one's self. [41]. Through metacognitive therapy [42], cognitive therapy, or cognitive behavioral therapy [43], these five depressogenic practices can be challenged and replaced with more mature and life affirming convictions and habits. These refer to the achievement of internal locus of control, external locus of attention, and the habit of disputing automatic negative thoughts. In addition to these practices typical of Western culture, the Asian techniques of meditation have also been found to significantly improve cognitive functioning and well-being, by stimulating left-brain activity $[16,44,45]$ and thus the positive emotionality associated with the behavioral 
activating system. Tongue-in-cheek, it is perhaps an irony of sorts that critical geographers' support of leftist politics as the way towards collective happiness has a geographical correlate in the intricate spatiality of the brain.

\section{The Hedonic Treadmill}

The formula of happiness I have just discussed captures the essence of decades of research in psychology, behavioural genetics, and neuroscience but fails to fully explain how happiness unfolds over time. As early as 1971, Brickman and Campbell alerted scholars to the reality of the hedonic treadmill: no matter how much an individual's conditions of living improve, after a short period of improved wellbeing, his/her level of happiness will return to its average set point, which the authors assumed at the time to be marked by emotional neutrality (i.e., neither happiness nor sadness). However, a later study ([15]; see also $[14,17])$ has reexamined the hedonic treadmill hypothesis and, while admitting that there remains a lot of evidence supporting it, argued for a revision and softening of the hypothesis in light of more recent and more reliable data. Specifically, Diener's research team introduces five qualifications to the earlier work of Brickman and Campbell: the set point of emotionality is not neutral $(75 \%$ to $80 \%$ of people report their average mood to be rather positive); different individuals have different set points (a discovery supported by the Minnesota Study of Twins Reared Apart and the recent work of [14]); there is no single global set point of happiness but a set of set points for distinct components such as negative emotionality, positive emotionality, and satisfaction with life (these sets of set points can go in different directions; as people age, their set points for both positive and negative emotionality decline mildly, while their set point for life satisfaction increases to some extent); the average level of happiness can be somewhat lowered by major life events such as widowhood, divorce, physical disability, and unemployment; and finally, the hedonic treadmill seems to operate with different speeds for different people. Thus, those individuals who deal with adversity through an active coping style (taking action to improve conditions) or emotional coping style (reappraising their feelings towards the traumatic event; [46]) return closer and faster to their pretrauma level of happiness than those individuals who use an avoidant coping style (denial).

For social geographers, this line of research might afford the possibility to scientifically justify the need for strong social services and support networks for those in need ${ }^{12}$. The Charles Murray-style conservative ideology that sees the "underclass" as lazy and complacent could perhaps be challenged on the grounds that what might seem to the uneducated eye as laziness, carelessness, and complacency is in fact the symptomatology of posttraumatic depression [47] and of an avoidant coping style $[48,49]$. This argument would need to direct attention to wider social processes (homophobia, patriarchy, capitalism, and racism; see [50]), while at the same time maintaining the possibility of overcoming their pernicious effects through the psychological empowerment of those most affected.
When all is said and done, the hedonic treadmill reminds us that happiness is perishable. At the very same time, it opens our eyes to the temporal games that our cortical space plays [50-52]. Most important is "the hammock game": what keeps us striving towards the achievement of a goal is the secret belief that once that goal is achieved, we will be able to relax in the hammock of life, blessed with perpetual happiness [17].

If we step back from the details of these empirical findings from positive psychology and behavioral genetics, it seems to me that the main challenge that social geographers have to confront is the robustly established large genetic component of interindividual differences in happiness. Should we give up our work because happiness is, allegedly, largely predestined? Should we focus our efforts on those $20-50 \%$ that are nongenetic?

Should we concentrate our forces on explaining that genetic determination is not incompatible ${ }^{13}$ with malleability? Or, should we criticise these findings on philosophical and methodological grounds (e.g., positivistic philosophy and methodological individualism pervade ${ }^{14}$ the story that psychology has to tell)? At the time of writing these thoughts, I do not have a clear answer to these questions (see $[53,54]$ ), but I hope that a larger awareness of these findings within social geography would stimulate a powerful response to this (potentially) politically regressive challenge.

\section{Conflict of Interests}

The author has no conflict of interests, financial or otherwise, regarding this paper.

\section{Endnotes}

1. I acknowledge the fact that social geographers are a heterogeneous group and that there are differences among them as to the aims of social geography (see, e.g., the contributions in [19]).

2. Positive psychology is the study of the determinants and components of happiness and well-being. For an inventory of definitions of happiness and an analysis of the relation between the often-conflated concepts of happiness and well-being, see $[9,10,55]$.

3. For a detailed explanation of genes and genetic mechanisms and their relationship with epigenetics see $[20,33]$.

4. It is important to keep in mind the fact that positive psychologists are themselves a highly heterogeneous group, with some (the hedonic tradition) more inclined towards behavioral genetics, whereas others (the eudaimonic tradition) remain closer in spirit to the older and far less threatening ideals of Maslow's humanistic psychology. In this paper, as I am about to show, I am primarily worried by the research undertaken by the first group. For the most recent developments within the eudaimonic tradition, see $[56,57]$.

5. The brain is a self-organising structure that maintains its long-term equilibrium through an intricate network of negative feedback loops. Whereas wide short-term 
fluctuations in happiness are possible, over the longterm, these negative feedback loops ensure that one's level of happiness homeostatically reverts to its set point (i.e., its average), itself, a function of the particular variants of genes (allele) that an individual happens to possess (cf. [7, 15]; for the first statistical demonstration of the existence of set points for happiness, see [14]).

6. Note, however, that the constructivist school of thought in affective neuroscience has launched the argument that persistent conscious effort (e.g., relearning through long-term psychotherapy) might create new brain pathways that, in time, become entrenched and, therefore, make relapse to darker moods less likely [58].

7. This is because most left-handers have dominating rightbrain activity (cf. [18]).

8. It is important to recall that the relation between genes, environments, and volition is subtle, highly interactive, and therefore, complex. See, for example, the comprehensive discussion in $[7,20]$.

9. It is encouraging that, despite knowledge of a genetic set point for happiness since the mid-1990s, research on the social, political, and environmental determinants of happiness has not been stifled by it. See, for example, the Well-being in Developing Countries research, or the many articles on socioenvironmental aspects of happiness published in the Journal of Happiness Studies (over 300 articles), Social Indicators Research (over 500 articles), and the Journal of Socio-Economics. From an epistemological standpoint, however, this kind of research will be less valuable than it seems if it fails, as it so often does, to statistically control for the confounding effects of genes.

10. We have to be aware in this context of the danger of unwittingly reciting one of neoliberalism's favored tropes (but see [59]).

11. This should not be construed to mean that the familial environment is totally irrelevant. The problem addressed is the relative ranking of the relevant causal factors.

12. More specifically, the beneficial active and emotional coping styles can be taught; it is next to impossible for individuals trapped into an avoidant coping style to bootstrap themselves out of it without external help (cf. [48]).

13. There is a growing critical engagement of geographers with the literatures on genetics and the biological sciences, more generally. See, for example, $[50,52]$ and chapter 8 in [39] and the references cited therein.

14. For critiques within psychology of logical positivism and methodological individualism see, for example, [6062]. These critiques make it possible to contest on principled grounds some of the loftier claims of positive psychology.

\section{References}

[1] D. Ballas and D. Dorling, "The geography of happiness," in The Oxford Handbook of Happiness, pp. 465-481, Oxford University Press, 2013.

[2] D. Harvey, Spaces of Hope Berkeley, University of California Press, Berkeley, Calif, USA, 2000.

[3] D. Massey, "When theory meets politics," Antipode, vol. 40, no. 3, pp. 492-497, 2008.

[4] N. Blomley, "The spaces of critical geography," Progress in Human Geography, vol. 32, no. 2, pp. 285-293, 2008.

[5] N. Castree, P. Chatterton, N. Heynen, W. Larner, and M. Wright, Eds., The Point Is to Change It: Geographies of Hope and Survival in an Age of Crisis, Antipode Book, Wiley-Blackwell, Oxford, UK, 2010.

[6] C. Barnett, "Geography and ethics: placing life in the space of reasons," Progress in Human Geography, vol. 36, no. 3, pp. 379388, 2012.

[7] R. B. Nes, "Happiness in behaviour genetics: findings and implications," Journal of Happiness Studies, vol. 11, no. 3, pp. 369-381, 2010.

[8] M. Seligman, Authentic Happiness, Free Press, New York, NY, USA, 2002.

[9] M. E. P. Seligman, "Positive health," Applied Psychology, vol. 57, no. 1, pp. 3-18, 2008.

[10] M. Seligman, Flourish: A Visionary New Understanding of Happiness and Well-Being, Free Press, New York, NY,USA, 2011.

[11] A. J. Oswald and S. Wu, "Objective confirmation of subjective measures of human well-being: evidence from the U.S.A," Science, vol. 327, no. 5965, pp. 576-579, 2010.

[12] R. Layard, "Measuring subjective well-being," Science, vol. 327, no. 5965, pp. 534-535, 2010.

[13] D. Lykken and A. Tellegen, "Happiness is a stochastic phenomenon," Psychological Science, vol. 7, no. 3, pp. 186-189, 1996.

[14] R. A. Cummins, N. Li, M. Wooden, and M. Stokes, "A demonstration of set-points for subjective wellbeing," Journal of Happiness Studies, vol. 15, no. 1, pp. 183-206, 2014.

[15] E. Diener, R. E. Lucas, and C. N. Scollon, "Beyond the hedonic treadmill: revising the adaptation theory of well-being," The American Psychologist, vol. 61, no. 4, pp. 305-314, 2006.

[16] R. J. Davidson, "Well-being and affective style: neural substrates and biobehavioural correlates," Philosophical Transactions of the Royal Society B: Biological Sciences, vol. 359, no. 1449, pp. 13951411, 2004.

[17] M. L. Kringelbach and K. C. Berridge, "Towards a functional neuroanatomy of pleasure and happiness," Trends in Cognitive Sciences, vol. 13, no. 11, pp. 479-487, 2009.

[18] S. Coren, The Left-Hander Syndrome: The Causes and Consequences of Left-Handedness, Vintage Books, New York, NY, USA, 1993.

[19] S. J. Smith, R. Pain, S. Marston, and J. P. Jones, Eds., The SAGE Handbook of Social Geographies, Sage, London, UK, 2009.

[20] T.-Y. Zhang and M. J. Meaney, "Epigenetics and the environmental regulation of the genome and its function," Annual Review of Psychology, vol. 61, pp. 439-466, 2010.

[21] C. Senik, "Wealth and happiness," Oxford Review of Economic Policy, vol. 30, no. 1, pp. 92-108, 2014.

[22] L. T. Eby, C. P. Maher, and M. M. Butts, "The intersection of work and family life: the role of affect," Annual Review of Psychology, vol. 61, pp. 599-622, 2010. 
[23] J. Haidt, The Happiness Hypothesis: Finding Modern Truth in Ancient Wisdom, Basic Books, New York, NY, USA, 2006.

[24] M. Harrow, B. G. Hansford, and E. B. Astrachan-Fletcher, "Locus of control: relation to schizophrenia, to recovery, and to depression and psychosis-a 15-year longitudinal study," Psychiatry Research, vol. 168, no. 3, pp. 186-192, 2009.

[25] D. Dorn, J. A. V. Fischer, G. Kirchgässner, and A. Sousa-Poza, "Is it culture or democracy? The impact of democracy and culture on happiness," Social Indicators Research, vol. 82, no. 3, pp. 505526, 2007.

[26] J. H. Fowler and N. A. Christakis, "Dynamic spread of happiness in a large social network: longitudinal analysis over 20 years in the Framingham heart study," British Medical Journal, vol. 337, Article ID a2338, 2008.

[27] L. E. Williams and J. A. Bargh, "Keeping one's distance: the influence of spatial distance cues on affect and evaluation," Psychological Science, vol. 19, no. 3, pp. 302-308, 2008.

[28] R. M. Raafat, N. Chater, and C. Frith, "Herding in humans," Trends in Cognitive Sciences, vol. 13, no. 10, pp. 420-428, 2009.

[29] H. Hitokoto and Y. Uchida, "Interdependent happiness: theoretical importance and measurement validity," Journal of Happiness Studies, 2014.

[30] S. Freud, An Outline of Psychoanalysis, Hogarth Press, London, UK, 1940.

[31] S. Freud, An Outline of Psychoanalysis, Hogarth Press, London, UK, 1979.

[32] J. O'Neill, Ed., Freud and the Passions, Pennsylvania University Press, University Park, Pa, USA, 1996.

[33] R. Plomin, Nature and Nurture: An Introduction to Human Behavioral Genetics, Wadsworth, London, UK, 2004.

[34] J. R. Harris, No Two Alike: Human Nature and Human Individuality, W. W. Norton \& Company, New York, NY, USA, 2006.

[35] K. Takano and Y. Tanno, "Self-rumination, self-reflection, and depression: self-rumination counteracts the adaptive effect of self-reflection," Behaviour Research and Therapy, vol. 47, no. 3, pp. 260-264, 2009.

[36] H. A. Ball, P. McGuffin, and A. E. Farmer, "Attributional style and depression," The British Journal of Psychiatry, vol. 192, no. 4, pp. 275-278, 2008.

[37] I. Blanchette and A. Richards, "The influence of affect on higher level cognition: a review of research on interpretation, judgement, decision making and reasoning," Cognition \& Emotion, vol. 24, no. 4, pp. 561-595, 2010.

[38] N. Thrift, "Bare life," in Dancing Bodies, H. Thomas and J. Ahmed, Eds., pp. 145-169, Routledge, London, UK, 2003.

[39] N. Thrift, Non-Representational Theory: Space, Politics, Affect, Routledge, London, UK, 2008.

[40] N. Thrift, "Lifeworld Inc-and what to do about it," Environment and Planning D: Society and Space, vol. 29, no. 1, pp. 5-26, 2011.

[41] G. Pratt, Working Feminism, Edinburgh University Press, Edinburgh, UK, 2004.

[42] A. Wells, Metacognitive Therapy for Anxiety and Depression, Guilford Press, New York, NY, USA, 2011.

[43] P. Cuijpers, F. Smit, E. Bohlmeijer, S. D. Hollon, and G. Andersson, "Efficacy of cognitive-behavioural therapy and other psychological treatments for adult depression: meta-analytic study of publication bias," The British Journal of Psychiatry, vol. 196, no. 3, pp. 173-178, 2010.
[44] I. Schreiner and J. P. Malcolm, "The benefits of mindfulness meditation: changes in emotional states of depression, anxiety, and stress," Behaviour Change, vol. 25, no. 3, pp. 156-168, 2008.

[45] P. Collard, N. Avny, and I. Boniwell, "Teaching mindfulness based cognitive therapy (MBCT) to students: the effects of MBCT on the levels of mindfulness and subjective well-being," Counselling Psychology Quarterly, vol. 21, no. 4, pp. 323-336, 2008.

[46] T. D. Wilson and D. T. Gilbert, "Explaining away: a model of affective adaptation," Perspectives on Psychological Science, vol. 3, no. 5, pp. 370-386, 2008.

[47] B. L. Ganzel, P. A. Morris, and E. Wethington, "Allostasis and the human brain: integrating models of stress from the social and life sciences," Psychological Review, vol. 117, no. 1, pp. 134-174, 2010.

[48] J. Heckhausen, C. Wrosch, and R. Schulz, "A motivational theory of life-span development," Psychological Review, vol. 117, no. 1, pp. 32-60, 2010.

[49] D. Simandan, "Entrenched patterns of hot cognition may explain stubborn attributes of the economic landscape," Journal of Women's Entrepreneurship and Education, no. 3-4, pp. 1-21, 2009.

[50] D. Simandan, "On how much one can take: relocating exploitation and exclusion within the broader framework of allostatic load theory," Health \& Place, vol. 16, no. 6, pp. 1291-1293, 2010.

[51] D. T. Gilbert and T. D. Wilson, "Why the brain talks to itself: sources of error in emotional prediction," Philosophical Transactions of the Royal Society B: Biological Sciences, vol. 364, no. 1521, pp. 1335-1341, 2009.

[52] D. Simandan, "On time, place and happiness," New Zealand Geographer, vol. 67, no. 1, pp. 6-15, 2011.

[53] D. Simandan, "The wise stance in human geography," Transactions of the Institute of British Geographers, vol. 36, no. 2, pp. 188-192, 2011.

[54] D. Simandan, "Kinds of environments: a framework for reflecting on the possible contours of a better world," The Canadian Geographer, vol. 55, no. 3, pp. 383-386, 2011.

[55] C. Peterson and M. Seligman, Eds., Character Strengths and Virtues: A Handbook and Classification, Oxford University Press, New York, NY, USA, 2004.

[56] A. M. Grant and B. Schwartz, "Too much of a good thing: the challenge and opportunity of the inverted U," Perspectives on Psychological Science, vol. 6, no. 1, pp. 61-76, 2011.

[57] J. Gruber, I. B. Mauss, and M. Tamir, "A dark side of happiness? How, when, and why happiness is not always good," Perspectives on Psychological Science, vol. 6, no. 3, pp. 222-233, 2011.

[58] B. Draganski, C. Gaser, V. Busch, G. Schuierer, U. Bogdahn, and A. May, "Neuroplasticity: changes in grey matter induced by training," Nature, vol. 427, no. 6972, pp. 311-312, 2004.

[59] T. C. Boas and J. Gans-Morse, "Neoliberalism: from new liberal philosophy to anti-liberal slogan," Studies in Comparative International Development, vol. 44, no. 2, pp. 137-161, 2009.

[60] B. D. Slife and F. C. Richardson, "Problematic ontological underpinnings of positive psychology: a strong relational alternative," Theory \& Psychology, vol. 18, no. 5, pp. 699-723, 2008.

[61] J. Kagan, "Historical selection," Review of General Psychology, vol. 13, no. 1, pp. 77-88, 2009.

[62] S. C. Yanchar, B. D. Slife, and R. Warne, "Critical thinking as disciplinary practice," Review of General Psychology, vol. 12, no. 3, pp. 265-281, 2008. 

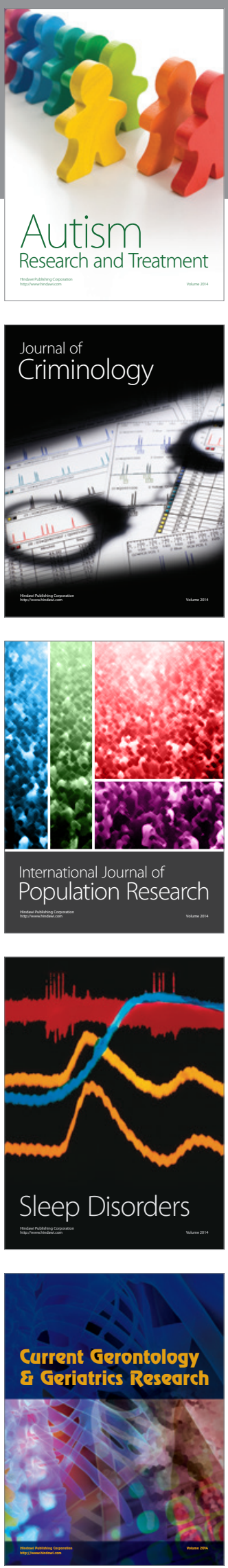
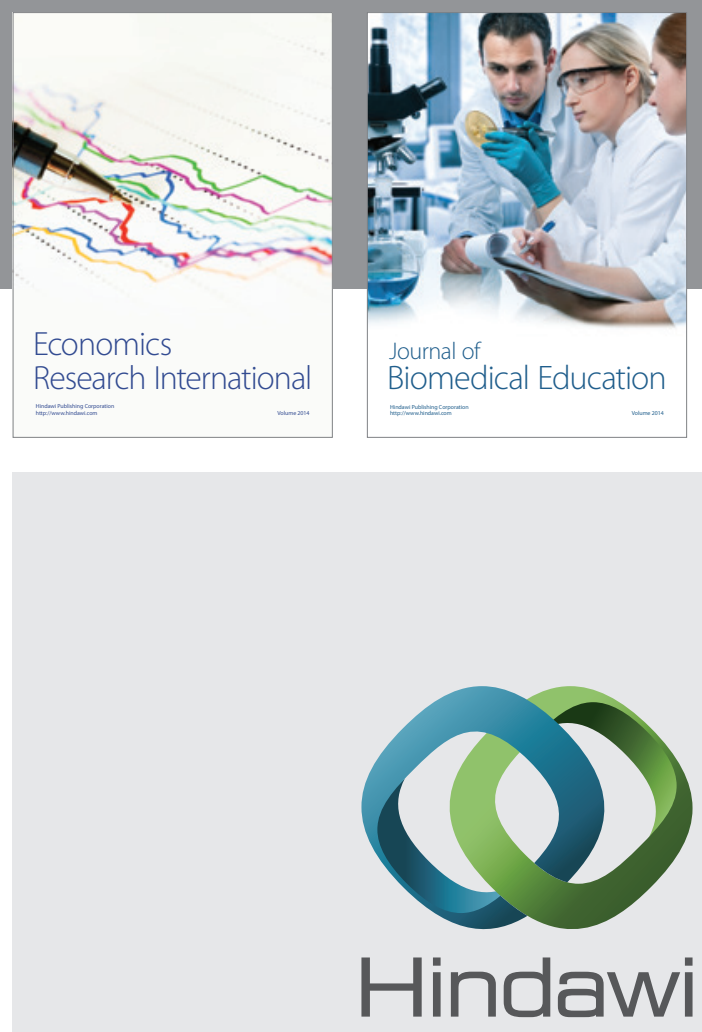

Submit your manuscripts at

http://www.hindawi.com
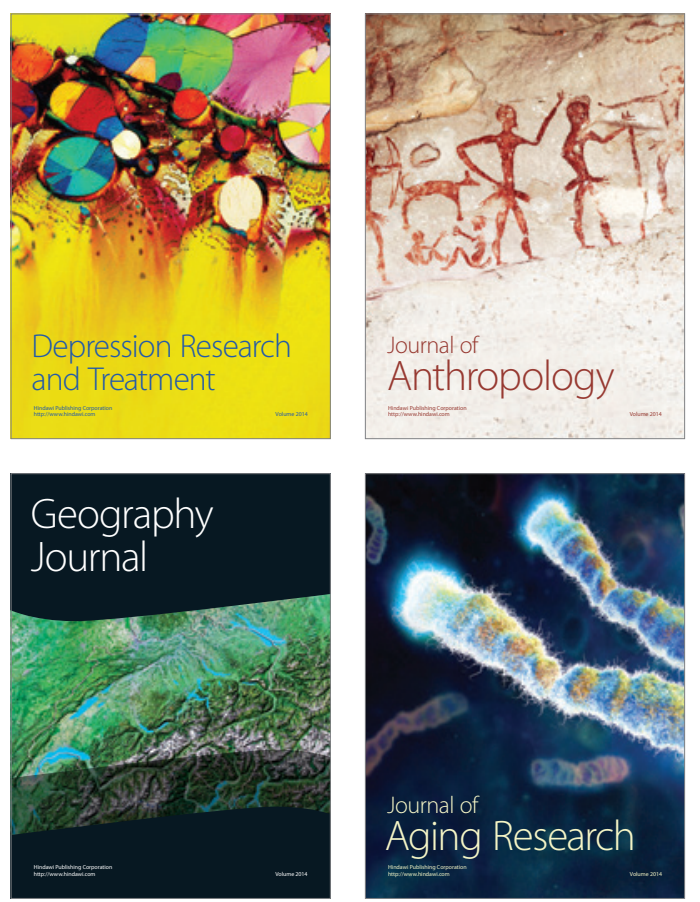
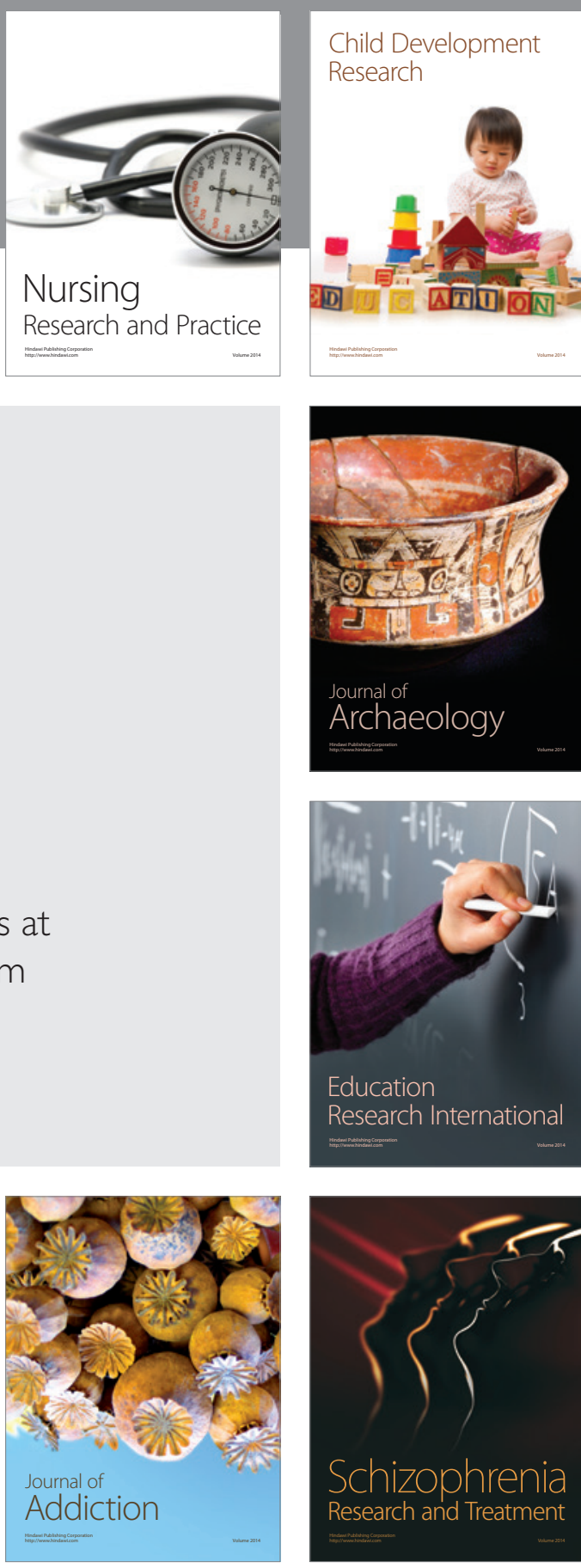

(D)
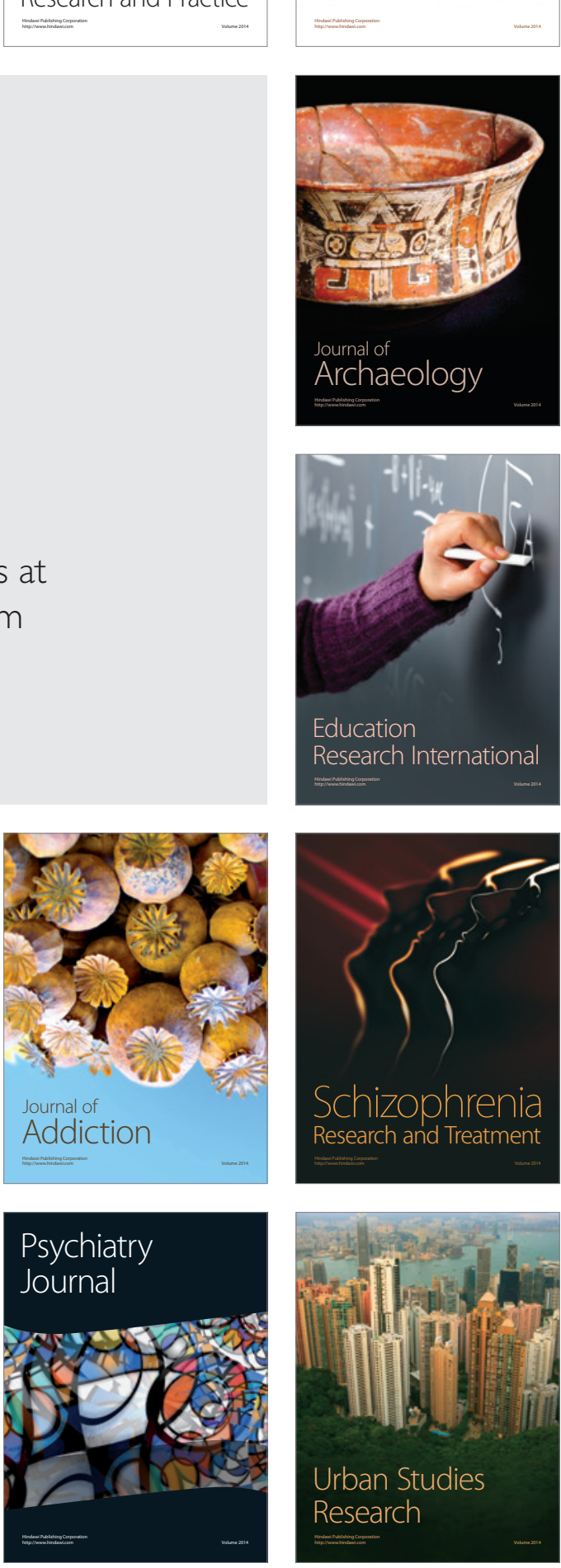